\title{
ТУБЕРКУЛЬОЗ ЛЕГЕНІВ: БІБЛІОМЕТРИЧНИЙ АНАЛІЗ
}

Туберкульоз легенів: бібліометричний аналіз

\section{І. В. Школа' ${ }^{1}$, Л. В. Гайова ${ }^{1}$, А. О. Деміхов ${ }^{2}$}

Національний медичний університет

імені О.О. Богомольця, м. Київ ${ }^{1}$

Сумський державний університет²

Резюме. Велика поширеність захворювання на туберкульоз, складне лікування (потребує багато часу та наполегливості) із супутнім комплексним підходом, який зумовлюється соціальною залежністю хвороби, інші аспекти роблять боротьбу із туберкульозом недостатньо ефективною, а в окремих країнах - 3 малопомітними перспективами. Хвороба нерідко супроводжується інвалідністю і навіть летальними випадками. Тому поширення інорекційної хвороби, у тому числі внаслідок повітряно-краплинної передачі, значно пов'язані з лікуванням, витратами часу та коштами. Недостатня відповідь на лікування із-за наявності феномену медикаментозної стійкості актуалізують необхідність удосконалення лікування з урахуванням сучасних досягнень медицини в різних країнах.

Мета дослідження - застосувати можливості програмного засобу VOSviewer в аналізі напрямків публікацій на тему туберкульозу легенів у web-базі даних Scopus.

Матеріали і методи. Матеріалом для даного дослідження були бібліометричні дані щодо наукових публікацій з web-бази даних Scopus, отриманих за запитом по ключовому слову «pulmonary tuberculosis » за період 1862-2021 рр. Обробку інфрормації проводили в програмі VOSviewer v.1.6.16. В ході роботи було проведено програмний аналіз 92,263 статей.

Результати. У сmammi розглянуто основні фуункціі програмного засобу VOSviewer задля дослідження наукових публікацій. Зроблено оцінку публікацій із питань туберкульозу легень у період 1862-2021 рр., інтерпретовано дані отриманих картограм з кластерами. Усього отримано 5 кластерів, які присвячені таким аспектам: ускладнення та діагностика, соціально залежні фрактори хвороби, вакцинація та генетично-імунологічні фрактори, фрармакологічний аспект та новітні підходи.

Висновки. Візуалізація продемонструвала, що в цілому найактивніше автори висвітлюють питання ускладнень та діагностики, а також соціально залежні фрактори хвороби, а менше пишуть про вакцинацію чи фрармакологічні аспекти.
Pulmonary tuberculosis: bibliometric analysis I. V. Schola ${ }^{1}$, L. V. Hayova ${ }^{1}$, A. O. Demikhov ${ }^{2}$

O. Bohomolets National Medical University, Kyiv ${ }^{1}$ Sumy State University ${ }^{2}$

e-mail: ihor.schoola@gmail.com

Summary. The high prevalence of tuberculosis, complex treatment (requires a lot of time and persistence) with a concomitant integrated approach, which is due to the social dependence of the disease, other aspects make the fight against tuberculosis ineffective, and in some countries - with little prospect. The disease is often accompanied by disability and even death. Therefore, the high prevalence of infectious diseases, including due to airborne transmission, significant time and money associated with treatment, insufficient response to treatment due to the phenomenon of drug resistance, the need to improve treatment taking into account modern advances in medicine in different countries.

The aim of the study - to use the capabilities of VOSviewer software in the analysis of publications in the field of pulmonary tuberculosis in the Scopus web database.

Materials and Methods. The material for this study was bibliometric data on scientific publications from the Scopus web database, obtained on request for the keyword "pulmonary tuberculosis" for the period 1862-2021. Information processing was performed in the program VOSviewer v.1.6.16. In the course of work the program analysis of 92,263 articles was carried out.

Results. The main functions of the VOSviewer software for research of scientific publications are considered in the article. The evaluation of publications on pulmonary tuberculosis in the period 1862-2021 is made, the data of the obtained cartograms with clusters are interpreted. A total of 5 clusters were obtained, which are devoted to the following aspects: complications and diagnosis, socially dependent disease factors, vaccination and genetic-immunological factors, pharmacological aspect and new approaches.

Conclusions. Visualization showed that, in general, the authors most actively cover issues of complications and diagnosis, as well as socially dependent factors of the disease, and write less about vaccination or pharmacological aspects. 
Ключові слова: туберкульоз легенів; VOSviewer; Scopus; бібліометричний аналіз; візуалізація; картограма; лікування.

\section{ВСТУП}

Сучасна наука, у тому числі медична, має в розпорядженні дуже багато методів та інструментів. А з розвитком бібліографрічних баз даних та інструментів для відстеження цитування статей, опублікованих в наукових виданнях, можливостей у дослідників стало ще більше. Так, бібліометрика дозволяє вивчати тематичні рубрики, прізвища авторів та назви журналів за темами публікацій, взаємозв'язок між темами публікацій тощо. Наукометрика має можливість вивчати динаміку кількості статей за темою, їх цитованість та ін.

Бібліометрія стала настільки популярною, що її використовують для підтримки рішень щодо ефрективності фрінансування наукових досліджень у певному напрямку щодо моніторингу розвитку наукових напрямків (наприклад у Великобританії проект Research Excellence Framework (REF) оцінює якість дослідницьких результатів університетів Об'єднаного Королівства та на цій основі виділяється фрінансування дослідникам [1]). Такий підхід має достатньо критики.

Так, триєдиною метою створення REF, як зазначено на сайті організації, є: забезпечити відповідальність за державні інвестиції у дослідження та надати докази переваг цієї інвестиції; надати порівняльну інорормацію та встановити репутаційні критерії для використання у секторі вищої освіти та для публічної інфрормації; інфрормувати про вибірковий розподіл фрінансування на дослідження. Перші оцінки REF здійснено у 2014 р., це є процес експертного огляду для кожної із 34 оцінок (експертами $€$ науковці, закордонні спеціалісти та користувачі досліджень). Серед цих оцінок важливе місце займає аналіз цитованості наукових публікацій.

У сучасному житті дослідники стикаються з величезним обсягом інорормації, який вже неможливо
Key words: pulmonary tuberculosis; VOSviewer; Scopus; bibliometric analysis; visualization; cartogram; treatment.

вручну обробити, тим паче, що кількість публікацій стрімко зростає з кожним днем. Для вирішення цього завдання створено VOSviewer [3], що спочатку представлений у статті Van Eck \& Waltman (2010) і більш пізніх [ 5, 6]. VOSviewer - це програмний інструмент для створення карт на основі даних мережі, а також для візуалізації та вивчення цих карт. Функціональні можливості VOSviewer (рис. 1):

Зазначений програмний продукт вже почали активно використовувати українські вчені, але поки що не в медичних дослідження. На сьогодні це застосовують тільки у соціальних та технічних науках.

Наше дослідження присвячено використанню можливостей VOSviewer для вивчення бібліометричних даних із тематики туберкульозу легень.

Велика поширеність захворювання на туберкульоз, складне лікування (потребує багато часу та наполегливості) із супутнім комплексним підходом, який зумовлюється соціальною залежністю хвороби, інші аспекти роблять боротьбу із туберкульозом недостатньо есрективною, а в окремих країнах - із малопомітними перспективами. Хвороба нерідко супроводжується інвалідністю і навіть летальними випадками.

Тому велика поширеність інфекційної хвороби, в тому числі унаслідок повітряно-краплинного шляху передачі, значно пов'язана з лікуванням, витратами часу та коштами. Недостатня відповідь на лікування із-за наявності феномену медикаментозної стійкості актуалізують необхідність удосконалення лікування з урахуванням сучасних досягнень медицини в різних країнах.

Наявні на даний момент ліки від туберкульозу - це переважно антибіотики. Але у 2016 та 2018 рр. були опубліковані результати досліджень, що обережно пропонують інші підходи до ліків. Але поки що клінічні випробовування проводять на тваринах.

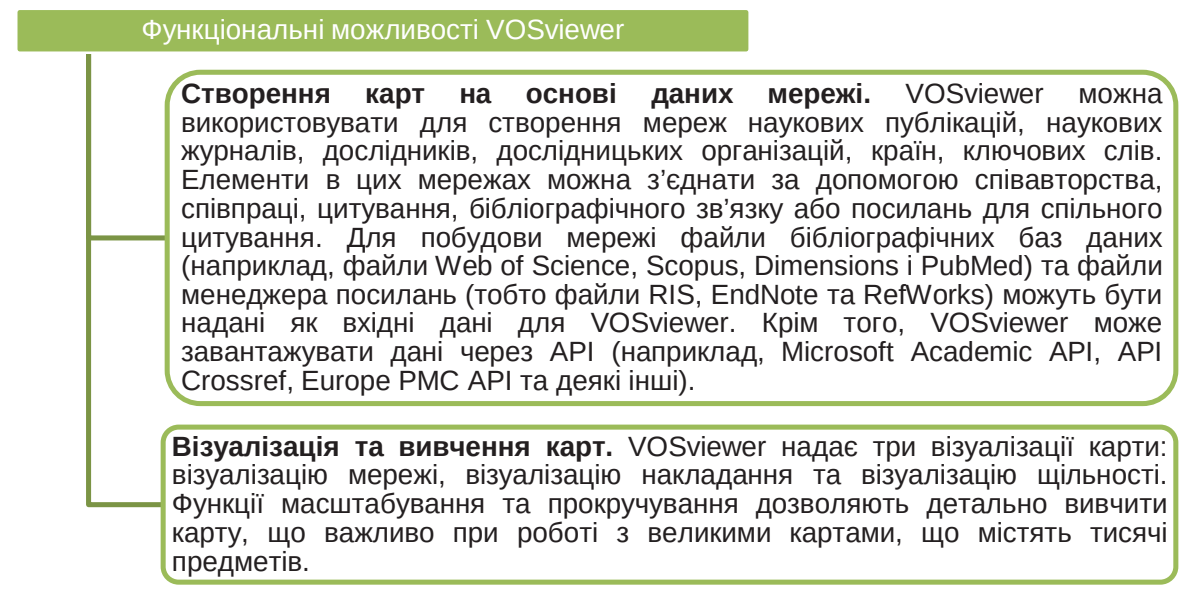

Рис. 1. Функціональні можливості VOSviewer згідно з керівництвом до програми [3].

ISSN 2706-6282(print)

ISSN 2706-6290(online)
Вісник медичних і біологічних досліджень

Bulletin of Medical and Biological Research
$3(9), 2021$ 
Поширеність туберкульозу дуже відрізняється по країнах. Україна, за даними ВОО3, належить до п'ятірки країн із найбільшою кількістю зареєстрованих випадків туберкульозу з розширеною резистентністю. Хвороба небезпечна ще й тим, що може мати тривалий перебіг у безсимптомній фрормі, а також тим, що внаслідок особливостей мікобактерії (немає плазмід) виникає феномен медикаментозної стійкості. Нині в лікуванні туберкульозу використовують одразу до 4 препаратів, найбільш вживаними серед яких є: «Ізоніазид», «Рифрампіцин», «Піразинамід», «Етамбутол», «Стрептоміцин».

Багато уваги приділяється комплексному підходу в лікуванні, який покликаний зменшити смертність від хвороби (сягає 4-8 \%): лікування ВІЛ-інфрікованих та осіб, які приймають ін'єкційні наркотики, осіб із недостатнім харчуванням унаслідок злиденності, та таких, що перебувають у в'язницях, притулках для безхатченків і біженців, інших категорій ризику.

Все зазначене підкреслює актуальність питання використання бібліометричного аналізу з тематики туберкульозу легень задля дослідження новітніх напрямків дослідницьких пошуків.

Метою дослідження було застосувати можливості програмного засобу VOSviewer в аналізі напрямків публікацій на тему туберкульозу легенів y web-базі даних Scopus.

\section{МАТЕРІАЛИ І МЕТОДИ}

Матеріалом для даного дослідження були бібліометричні дані щодо наукових публікацій з webбази даних Scopus [2], отриманих за запитом за ключовим словом «pulmonary tuberculosis» у період 1862-2021 рр. Обробка інформації проводилася в програмі VOSviewer v.1.6.16. У ході роботи був проведений програмний аналіз 92263 статей.

\section{РЕЗУЛЬТАТИ Й ОБГОВОРЕННЯ}

У ході аналізу наукових публікацій, отриманих за запитом за ключовим словом «pulmonary tuberculosis» (також автоматично пропонується варіант «lung tuberculosis»), встановлено, що перша публікація датується 1862 р.

Автори проводили аналіз наукових публікацій 3 бази даних Scopus [2], хоча база Pubmed [4] фрактично запропонувала кількість статей, що незначно відрізнялася від тієї, що є у Scopus - 95697 статей проти 92 263. Головна причина - можливість користуватися необхідними опціями для аналізу була в авторів саме у базі Scopus.

Необхідно зазначати, що попередньо пошуки автори проводили за запитом TITLE-ABSKEY (pulmonary AND tuberculosis), що виявило 99114 результатів. Галузі, в яких є найбільша кількість публікацій, це: медицина - 92 263, імунологія та мікробіологія - 5764, біохімія, генетика та молекулярна біологія - 5727, фрармакологія, токсикологія та фрармацевтика - 2232, мультидисциплінарні - 1407. Потрібно зазначити, що одна публікація може належати одразу до кількох галузей.

Але оскільки не всі вони відповідали медичній галузі, то запит було уточнено: TITLE-ABSKEY (pulmonary AND tuberculosis) AND (LIMITTO (SUBJAREA, «MEDI»)). В результаті отримано 92263 документів.

Використовуючи функцію «Analyze search results», можна проаналізувати публікації по роках, за авторами, афріліацією, країною/територією, типом (стаття, книга), предметною галуззю, спонсором.

Отже, перші публікації 1862 р. присвячені питанням того, як наявність туберкульозу легень ускладнила стан пацієнтів 3 іншими хворобами та питанням помилкових діагнозів.

Туберкульоз відомий людству ще з античних часів. Хвороба забрала багато мільйонів життів, мала певні періоди значних епідемій та певної стабілізації ситуації. На рисунку 2 унаочнено динаміку публікацій із тематики легеневого туберкульозу за період до Другої світової війні та по п'ятирічних періодах після неї і до сьогодення.

Так, у період 1976-2005 рр. помітне явне зменшення інтересу дослідників до тематики туберкульозу, але після 2005 р. спостерігається явна активізація. Це пов'язано з тим, що у 2006 р. було розроблено Глобальний план подолання туберкульозу (Global Plan to Stop Tuberculosis), а згодом, у 2014 р., на Генеральній Асамблеї ВООЗ прийнято Стратегію подолання туберкульозу (WHO End TB Strategy).

За типом джерела публікації є переважно журналами: журнал - 91 879, книга - 175, книжкова серія - 64, матеріали конференції - 44, торговий журнал - 1, невизначене - 114.

Фільтр за прізвищем авторів дав можливість визначити тих, у кого найбільше публікацій із тематики туберкульозу легенів: A. D. Harries - 157, G. B. Migliori - 116, W. J. Koch - 114, J. VIDAL - 113, D. A. Mitchison - 112, P. R. Donald - 103, J. J. Yim 98, M. Pai - 97, A. Zumla - 95, D. Menzies - 92.

Найбільш цитовані публікації це: R. Lozano, M. Naghavi, K. Foreman, etc. [7] - кількість цитувань - 8687; C. J. L. Murray, A. D. Lopez [8] - кількість цитувань-5426; M. S. Cohen, Y. Q. Chen, M. McCauley, etc. [9] кількість цитувань - 4954.

Фільтр за країною дозволив визначити, що публікації групуються наступним чином: США - 9216, Великобританія - 4738, Індія - 4489, Японія - 4486, Китай - 2589, Німеччина - 2381, Франція - 2064, Південна Африка - 2020, Південна Корея - 1631, Іспанія - 1501 та ін. Тобто на першу десятку країн приходиться більше третини публікацій за аналізованою тематикою. 


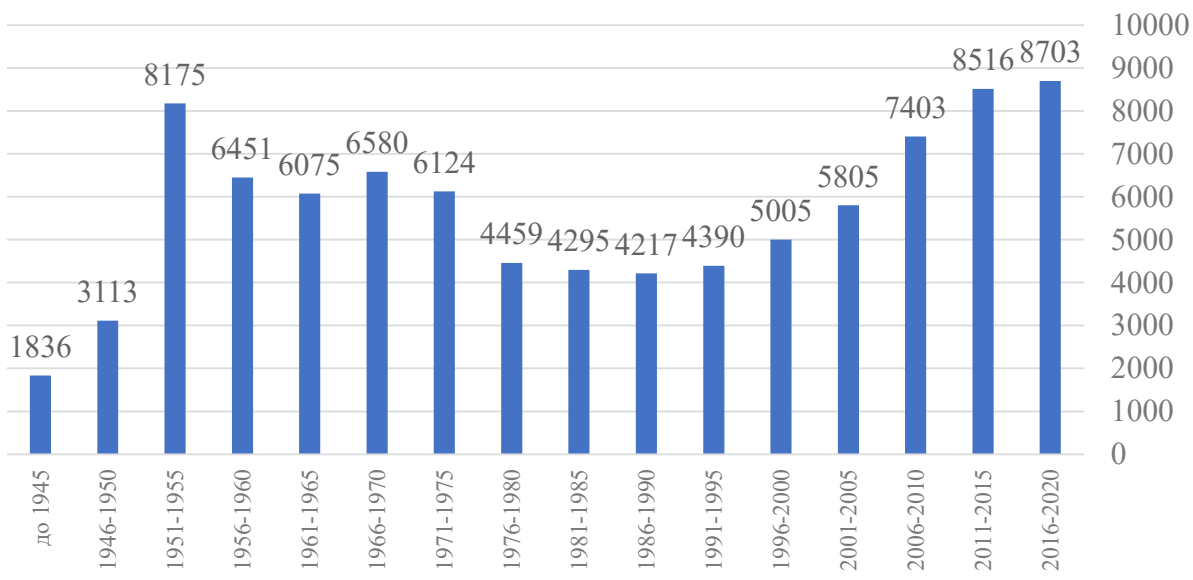

Рис. 2. Динаміка кількості публікацій за запитом TITLE-ABS-KEY (pulmonary AND tuberculosis) AND (LIMIT-TO (SUBJAREA, «MEDI»)).

Фільтр за асріліацією дав можливість визначити, що явно переважаючого лідера немає. На десятку перших приходиться трохи більше 5 \% публікацій: Кейптаунський університет - 675, Університет Стелленбоша - 588, Лондонська школа гігієни та тропічної медицини - 565, Центр контролю та профілактики захворювань - 554, Організація всесвітнього здоров'я (Mondiale de la Santé) - 472, Рада медичних досліджень Південної Афррики - 437, Імперський коледж Лондона - 381, Інститут дослідження туберкульозу в Індії - 378, Всеіндійський інститут медичних наук (Нью-Делі) - 368, Калісорнійський університет (Сан-Франциско) - 327.

Розподіл публікацій за мовою виглядає наступним чином: англійська - $51 \%$, російська - $12 \%$, французька-6\%, німецька-5\%, італійська-4\%, інші-22\%.
Спонсорами для фрінансування досліджень виступили: національні інститути здоров'я - 2237 , Міністерство охорони здоров'я та соціальних служб США - 2038, Національний інститут алергії та інфрекційних хвороб - 1584, Рада медичних досліджень -513, Національний інститут серця, легенів та крові (США) - 460, Міжнародний центр Фогарті - 394, Національний природничий фонд Китаю - 344, Дослідження та інновації Великобританії - 340 та ін.

Для побудови карти ми обрали наукові публікації 5 останніх років із найновішими досягненнями.

Отже, далі була побудована карта взаємозв'язків між найбільш вживаними ключовими словами за аналізованою тематикою із використанням режиму Network Visualization (рис. 3). Дана карта створена, зважаючи на мінімальну кількість ключових слів,

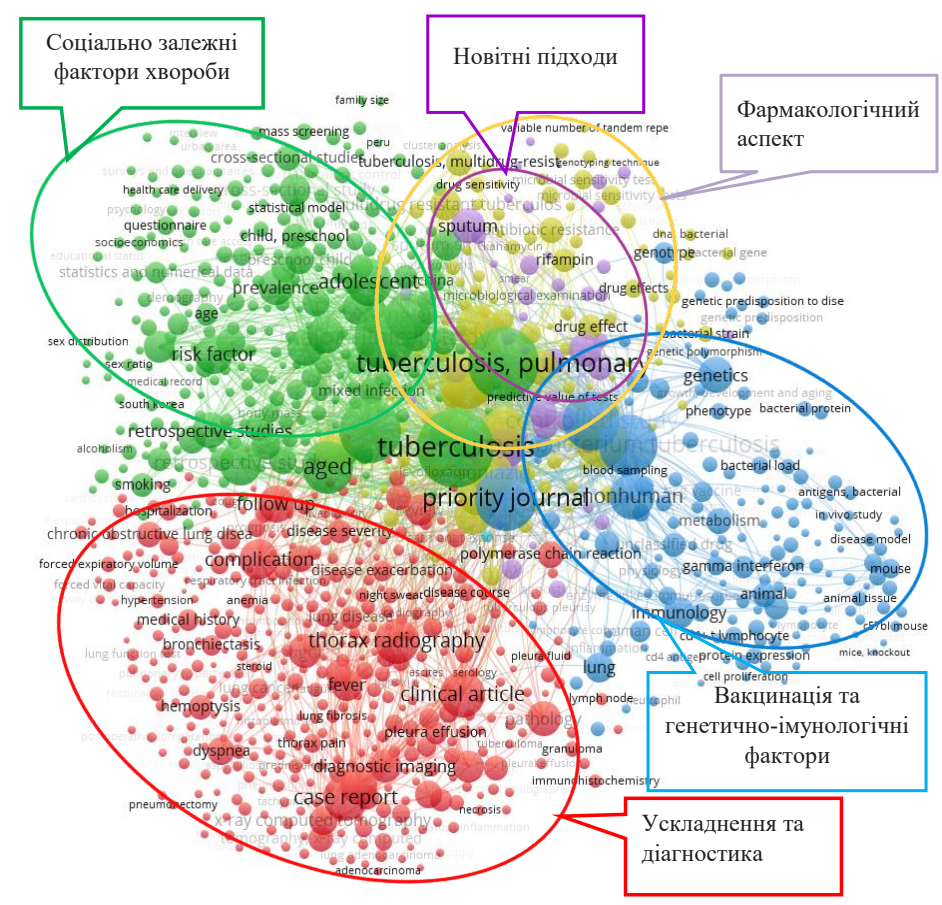

Рис. 3. Карта взаємозв'язків між найбільш вживаними ключовими словами за тематикою туберкульозу легенів, що згруповані за кластерами за період 2016-2020 pp. 
які беруться для побудови карти - occurrences. Усього більше 30 тис. ключових слів та майже 6000 з'єднань.

Чим більше розмір «бульбашки» на карті, тим частіше зустрічається певне ключове слово (словосполучення) у дослідженнях. Картограма розділена на області різного кольору, що допомагає у візуалізації кластерів.

Усього отримано 5 кластерів, характеристика яких наведена у таблиці: червоний (ускладнення та діагностика), зелений (соціально залежні фрактори хвороби), синій (вакцинація та генетично-імуноло- гічні фрактори), гірчичний (фармакологічний аспект) та фріолетовий (новітні підходи).

Дана візуалізація продемонструвала, що в цілому найактивніше автори висвітлюють питання ускладнень та діагностики, а також соціально залежні фрактори хвороби, а менше пишуть про вакцинацію чи фармакологічні аспекти.

Отже, результати даного бібліометричного аналізу можна використати з метою систематизації матеріалів дослідження задля пошуку наявних напрямків досліджень у межах сформульованої авторами більш широкої тематики.

Таблиця. Характеристика кластерів за ключовими словами

\begin{tabular}{|c|c|c|}
\hline Кластер & $\begin{array}{c}\text { Кількість } \\
\text { тем/items }\end{array}$ & Опис \\
\hline Кластер 1 (червоний) & 411 & $\begin{array}{l}\text { Абдомінальний туберкульоз, абсцес, анемія, анорексія, антибіотикотерапія, } \\
\text { астма, атопія, біопсія, бронхоскопія, бактеріальна пневмонія, нестача маси } \\
\text { тіла, бронхоскопія, смертельні випадки, кашель, цитологія, креатинін, діарея, } \\
\text { діагностичні помилки, хронічне захворювання, депресія, автоімунне захворю- } \\
\text { вання, сімейний анамнез, госпіталізація, летальність, лейкоцити, лейкопенія, } \\
\text { рак легенів, гранулематоз, фрлуконазол, гіпоксія, плацебо, малярія, мікобакте- } \\
\text { рії, спірометрія, слабкість, васкуліт, саркоїдоз, нейтропенія, міалгія, головний } \\
\text { біль, радіографрія, цефтріаксон, котримоксазол, імуноглобулін, ітраконазол, } \\
\text { менінгіт, пневмоторакс, сепсис, силікоз, пірідоксин тощо }\end{array}$ \\
\hline Кластер 2 (зелений) & 261 & $\begin{array}{l}\text { Алкоголізм, фрактор віку, коморбідність, діабет } 2 \text { типу, пацієнт високого ризику, } \\
\text { новонароджені, аналіз витрати-вигоди, педіатрія, Індія, Іран, Пакистан, Аф- } \\
\text { рика, Ефіопія, Перу, Великобританія, США, Іспанія, бідність, ВІЛ, ризик інорі- } \\
\text { кування, відношення шансів, сільське населення, вагітність, вітамін D, аналіз } \\
\text { харкотиння, якість життя, куріння, виживання, соціально-економічні фактори, } \\
\text { витрати на лікування, соціальний статус, розмір родини, програми охорони } \\
\text { здоров'я, туберкуліновий тест тощо }\end{array}$ \\
\hline Кластер 3 (синій) & 159 & $\begin{array}{l}\text { Біологічний маркер, БЦЖ-вакцина, бактеріальна вірулентність, аналіз крові, ге- } \\
\text { нетичний поліморфізм, генотип, імунна відповідь, інтерлейкін-2, інтерлейкін-4, } \\
\text { інтерлейкін-8, інтерлейкін-10, гамма-інтерферон, Т-лімфроцити, туберкулін, вак- } \\
\text { цинація, тваринні клітини, експерименти на тваринах, миші, макрофраги тощо }\end{array}$ \\
\hline Кластер 4 (гірчичний) & 114 & $\begin{array}{l}\text { Резистентність до антибіотиків, туберкулінові агенти, атипічні мікобактерії, ци- } \\
\text { клосерин, ефрективність ліків, резистентність до ліків, фрармакокінетика, амок- } \\
\text { сицилін, офрлоксацин, клофразимін, піразинамід, рифрампіцин, фрлуконазол, мок- } \\
\text { сифрлоксацин, макролід, левофрлоксацин, лікування, кларитроміцин, канаміцин, } \\
\text { етамбутол, ізоніазид, неефрективне лікування, рекурентні інфрекції тощо }\end{array}$ \\
\hline $\begin{array}{l}\text { Кластер } 5 \text { (фріолето- } \\
\text { вий) }\end{array}$ & 48 & $\begin{array}{l}\text { Культури бактерій, тест молекулярної діагностики, діагностичні тести, помил- } \\
\text { ково негативний результат, помилково позитивний результат, мікроскоп, мікро- } \\
\text { скопія, пілотне дослідження, діагностичні тести, пілотне дослідження, сеча, } \\
\text { цереброспінальна рідина, полімеразна реакція, аналіз харкотиння тощо }\end{array}$ \\
\hline
\end{tabular}

\section{ВИСНОВкИ}

1. Бібліометричний аналіз та програма VOSviewer значно розширюють можливості та полегшують роботу дослідника з метою структуризації даних про наукові публікації (у даному випадку - за тематикою туберкульозу легенів).
2. У процесі побудови карт було отримано 5 кластерів, що допомогло систематизувати інформацію відповідно до логічного змісту. Це дозволило виявити наявні тренди в публікаціях за останні роки та обґрунтувати напрямки подальших досліджень у межах тематики туберкульозу легенів. 


\section{СПИСОК ЛІТЕРАТУРИ}

1. Research Excellence Framework. - Access mode : https://www.ref.ac.uk/

2. Scopus. - Access mode : https://www.scopus.com/ $\mathrm{com} /$

3. Vosviewer. - Access mode : https://www.vosviewer.

4. Pubmed. - Access mode : https://pubmed.ncbi.nlm. nih.gov/

5. Van Eck N. J. Software survey: VOSviewer, a computer program for bibliometric mapping / N. J. Van Eck, L. Waltman // Scientometrics. - 2010. - Vol. 84 (2). P. 523-538.

6. Van Eck N. J. Citation-based clustering of publications using CitNetExplorer and VOSviewer / N. J. Van Eck, L. Waltman // Scientometrics. - 2017. - No. 2. - P. 1053-1070.

\section{REFERENCES}

1. Research Excellence Framework. Available from: https://www.ref.ac.uk/

2. Scopus. Available from: https://www.scopus.com/

3. Vosviewer. Available from: https://www.vosviewer. com/

4. Pubmed. Режим доступу: https://pubmed.ncbi.nlm. nih.gov/

5. Van Eck NJ, Waltman L. Software survey: VOSviewer, a computer program for bibliometric mapping. Scientometrics. 2010;84(2): 523-38.

6. Van Eck NJ, Waltman L. Citation-based clustering of publications using CitNetExplorer and VOSviewer. Scientometrics. 2017;2: 1053-70.
7. Lozano R. Global and regional mortality from 235 causes of death for 20 age groups in 1990 and 2010: A systematic analysis for the Global Burden of Disease Study 2010 / R. Lozano, M. Naghavi, K. Foreman [et al.] // The Lancet. - 2012. - Vol. 380 (9859). - P. 2095-2128.

8. Murray C. J. L. Alternative projections of mortality and disability by cause 1990-2020: Global Burden of Disease Study / C. J. L. Murray, A. D. Lopez // Lancet. - 1997. Vol. 349 (9064). - P. 1498-1504.

9. Cohen M. S. Prevention of HIV-1 infection with early antiretroviral therapy / M. S. Cohen, Y. Q. Chen, M. McCauley // New England Journal of Medicine. - 2011. Vol. 365 (6). - P. 493-505.

7. Lozano R, Naghavi M, Foreman K. Global and regional mortality from 235 causes of death for 20 age groups in 1990 and 2010: A systematic analysis for the Global Burden of Disease Study 2010. The Lancet. 2012; 380(9859): 2095-128.

8. Murray CJL, Lopez AD. Alternative projections of mortality and disability by cause 1990-2020: Global Burden of Disease Study. Lancet. 1997;349(9064): 1498-504.

9. Cohen MS, Chen YQ, McCauley M. Prevention of HIV1 infection with early antiretroviral therapy. New England Journal of Medicine. 2011;365(6): 493-505.

Отримано 02.08.21 